\title{
Broiler Chicken
}

National Cancer Institute

\section{Source}

National Cancer Institute. Broiler Chicken. NCI Thesaurus. Code C76362.

Derived from a cross between a white cornish male and a barred rock female in the 1930s, modern broilers are an F2 hybrid of broiler breeds characterized by high fecundity and fast growth. Broiler chickens are raised commercially for their meat and will grow to be 3-6 pounds by 8 weeks of age but tend to be afflicted by health problems related to this fast growth, including skeletal weakness, congestive heart failure, and a decrease in fertility. 